\title{
Analytical Hierarchy Process Providing Loans to the North Sumatra Regional Police Cooperative Using the Analytical Hierarchy Process
}

\author{
Rizaldy Khair \\ Politeknik LP3I Medan, Indonesia \\ Email : rizaldyk.lp3i@gmail.com
}

Received: 25 April 2021

Revised : 27 Mei 2021

Accepted: 28 Juny 2021

(C) 2021 The Author: Published by. Cattleya Darmaya Fortuna

\begin{abstract}
Loans for civil servants and police employees must be given to employees who are entitled to receive them. Lending without any criteria makes other employees not accept them. Lending using criteria ensures that the employee given the loan is an employee who deserves to receive it. The ahp method is able to complete the selection of employees who are eligible for the loan. Because of the criteria that can determine the weight value for each attribute, and then proceed with a ranking process that will select the best alternative from a number of alternatives. In this case, the alternative in question is the one who is entitled to receive a loan based on attributes, or determining criteria in selecting employees who are eligible to receive loans. Based on the ranking, Juliana Situmorang's employee has the highest score of 0.977 compared to other employees. The ahp method is the right step in determining employees who are eligible to receive loans.
\end{abstract}

Keywords: Loans, Cooperatives, Analytical Hierarchy Process

\section{INTRODUCTION}

The North Sumatra Regional Police Cooperative Center (PUSKOPPOLDASU) is a business forum run by a collection of PNS/POLRI areas of North Sumatra which is one of the cooperatives engaged in savings and loans that serves loans to all ranks of PNS/POLRI in the North Sumatra region. Savings and loan cooperatives are one of the financial institutions whose business activities are to collect funds from their members, then distribute them back to members who need these funds. One of its activities is the provision of money loans to its members. The goal is to provide an opportunity for its members to get easy loans and low interest rates. Efforts that can be made to improve the welfare of cooperatives, namely in money lending activities, need to be developed so that Puskoppoldasu can carry out its function of providing money loans to its members.

Until finally, the community established credit cooperatives with the aim of helping their people who were in debt with moneylenders [1]. Various kinds of products are offered by cooperatives to their members, one of which is a savings account and loan services [2]. Any loans to cooperatives with low interest [3]. Cooperatives have an important role in Indonesia's economic progress [4]. Cooperatives should be able to stand alone in an effort to prosper and members should be able to [5]. Information is very important in supporting the course of a company to achieve its desired goals [6]. The history of the formation of cooperatives in the past [7]. A decision support system is an 
information-generating system aimed at a particular problem that must be solved by the manager and can assist the manager in making decisions. Decision support systems are an integral part of the totality of the overall organizational system. An organizational system includes physical systems, decision systems, and information systems [8]. The decision support system is designed to support all stages of decision making, starting from identifying problems [9]. Decision support systems are not intended to replace the roles of decision makers [10]. The system is used to support decision making in an organization, company, or institution [11]. Select relevant data and determine the approach used in the decision-making process [12].

The Analytical Hierarchy Process method provides the best selection results from values that are considered unclear [13]. One method that is relevant and has a calculation of the value of consistency in determining the priority level of the criteria is the Analytical Hierarchy Process method [14]. One of the functions or services provided by cooperatives is lending [15]. AHP is a method of making decisions on the problem of determining the priority of choices from various alternatives or multiple criteria [16]. AHP can provide solutions for this SPK application to help complete credit decisions [17]. This decision support model will describe a complex multi-factor or multi-criteria problem in a hierarchy. The hierarchy is defined as a representation of a complex problem. Constraints faced by the Puskoppoldasu management in the process of providing loans, there are borrowers who cannot account for their obligations or cannot repay their loans in accordance with the agreement that has been agreed by both parties. This is because Puskoppoldasu in realizing the loan only provides a decision whether or not a borrower is given a capital loan, without taking into account the percentage of the feasibility value of the loan. This assessment was due to the difficulty of the management in calculating the percentage of loan eligibility whose parameters were income, employment, collateral value and credit status, which resulted in losses to Puskoppoldasu.

The problem faced by Puskoppoldasu, it is necessary to build a decision support system that will help determine who is entitled to get the loan. The model used in this decision support system is the Analytical Hierarchy Process (AHP). This method was chosen because it can determine the weight value for each attribute, then proceed with a ranking process that will select the best alternative from a number of alternatives. In this case, the alternative in question is the one entitled to receive a loan based on the specified criteria.

\section{METHODS}

\section{Loan}

Loans are a type of debt that can involve all types of tangible objects, although they are usually identified with monetary loans. Like any other debt instrument, a loan requires a redistribution of financial assets over time between the borrower (the debtor) and the debtor (the creditor).

\section{Analytical Hierarchy Process}

In solving problems with the Analytical Hierarchy Process (AHP), several principles must be understood, including :

1. Creating a Hierarchy

Complex systems can be understood by breaking them down into supporting elements, arranging elements in a hierarchy and combining them or synthesizing them.

2. Assessment criteria and alternatives

Kriteria Criteria and alternatives were carried out by pairwise comparisons. According to (Saaty, 1988), a scale of 1 to 9 is the best scale for expressing opinions.. 
3. Synthesis of priority

For each criterion and alternative, pair-wire comparisons are necessary. The relative comparison values of all alternative criteria can be adjusted according to predetermined judgments to produce weights and priorities. Weights and priorities are calculated by manipulating the matrix.

4. Logical Consistency

Consistency has two meanings. First, similar objects can be grouped according to uniformity and relevance. Second, it concerns the degree of relationship between objects based on certain criteria.

Procedure Method Process

Basically, the procedures or steps in the Analytical Hierarchy Process (AHP) method include:

1. Defining the problem and determining the desired solution, then compiling a hierarchy of the problems encountered. The goal of the hierarchy is to set goals that are the goals of the system as a whole at the top level.

2. Determining the priority of elements

a. The first step in determining the priority of elements is to make a pair comparison, which is to compare elements in pairs according to the given criteria.

b. The pairwise comparison matrix is filled in using numbers to represent the relative importance of an element to other elements.

3. Synthesizing

The considerations for pairwise comparisons were synthesized to obtain the overall priority. The things to do in this step are:

a. Sum the values of each column in the matrix..

b. Divide each value in the column by the total of the corresponding column.to obtain a normalized matrix..

c. Add up the values for each row and divide by the number of elements to get the average value..

4. Mesuring Consistency

In decision making, it is important to know how good the consistency is because we don't want judgmental decisions with low consistency. The things that are done in this step are: Multiply each value in the first column by the relative priority of the first element, the value in the second column by the relative priority of the second element and so on.

a. Sum each row

b. The result of the row sum is divided by the corresponding relative priority element.

c. Add the quotient above with the number of elements, the result is called

Calculate the Consistency Index $(\mathrm{CI})$ with the formula: $\mathrm{CI}=(\lambda$ maks-n $) / \mathrm{n}$

Where $\mathrm{n}$ denotes the number of elements.

5. Calculate the Consistency Ratio (CR) with the following formula:

$\mathrm{CR}=\mathrm{CI} / \mathrm{RC}$

Where $\mathrm{CR}=$ Consistency Ratio

$\mathrm{CI}=$ Consistency Index

$\mathrm{IR}=$ Indeks Random Consistency

\section{RESULTS \& DISCUSSION}

\section{Charging Criteria}


Criteria serve to input the values of the criteria used in the system. In filling in the criteria, there are 3 data that can be entered, namely criteria, sequence numbers and information.

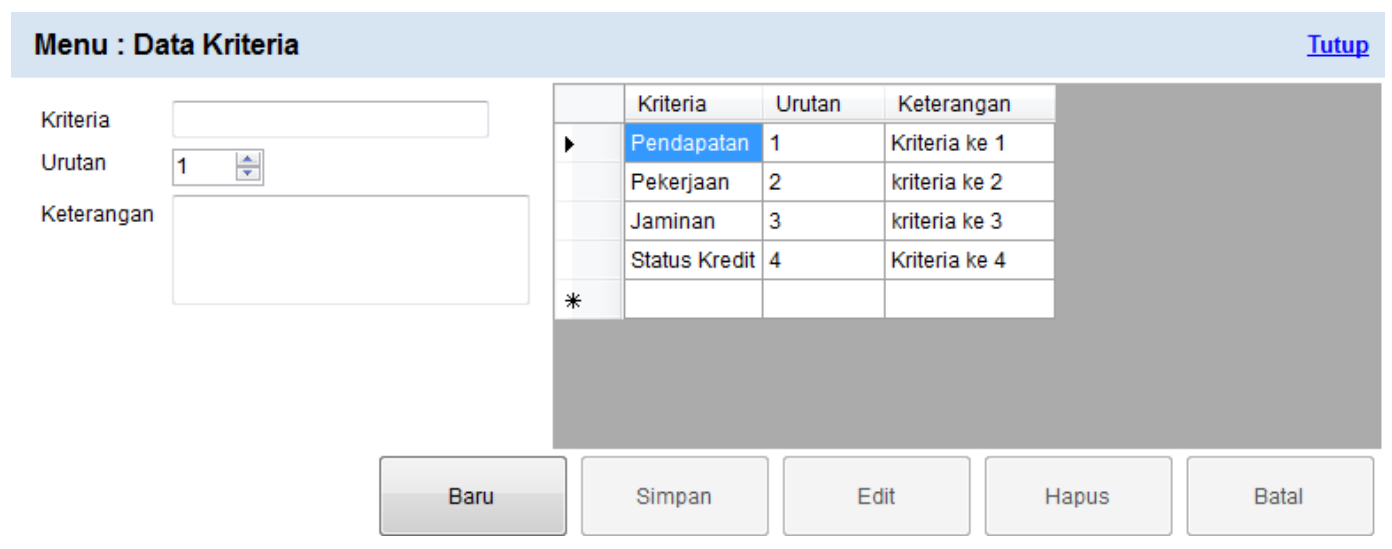

Figure 1 : Filling Criteria

Sub-criteria are determined after the criteria, therefore before filling in the subcriteria then the user must fill in the criteria first. There are 4 data that must be filled in the sub-criteria, namely criteria, sub-criteria, sequence of sub-criteria and information.

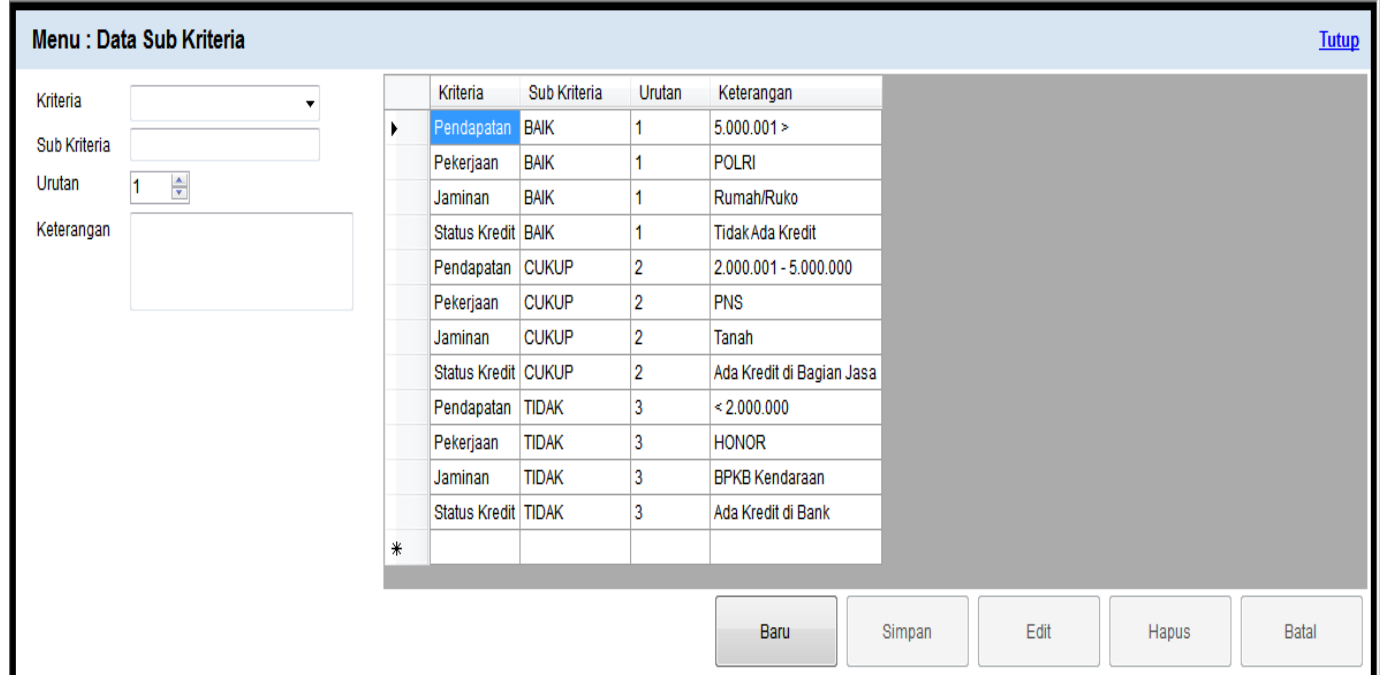

Figure 2 : Filling in Sub Criteria

The alternative is the data from the object's initiation that will be determined by the decision. In alternative filling, there are 10 data, namely borrower number, name, ID card number, address, telephone number, place of birth, date of birth, gender, marital status, and name of husband/wife. 


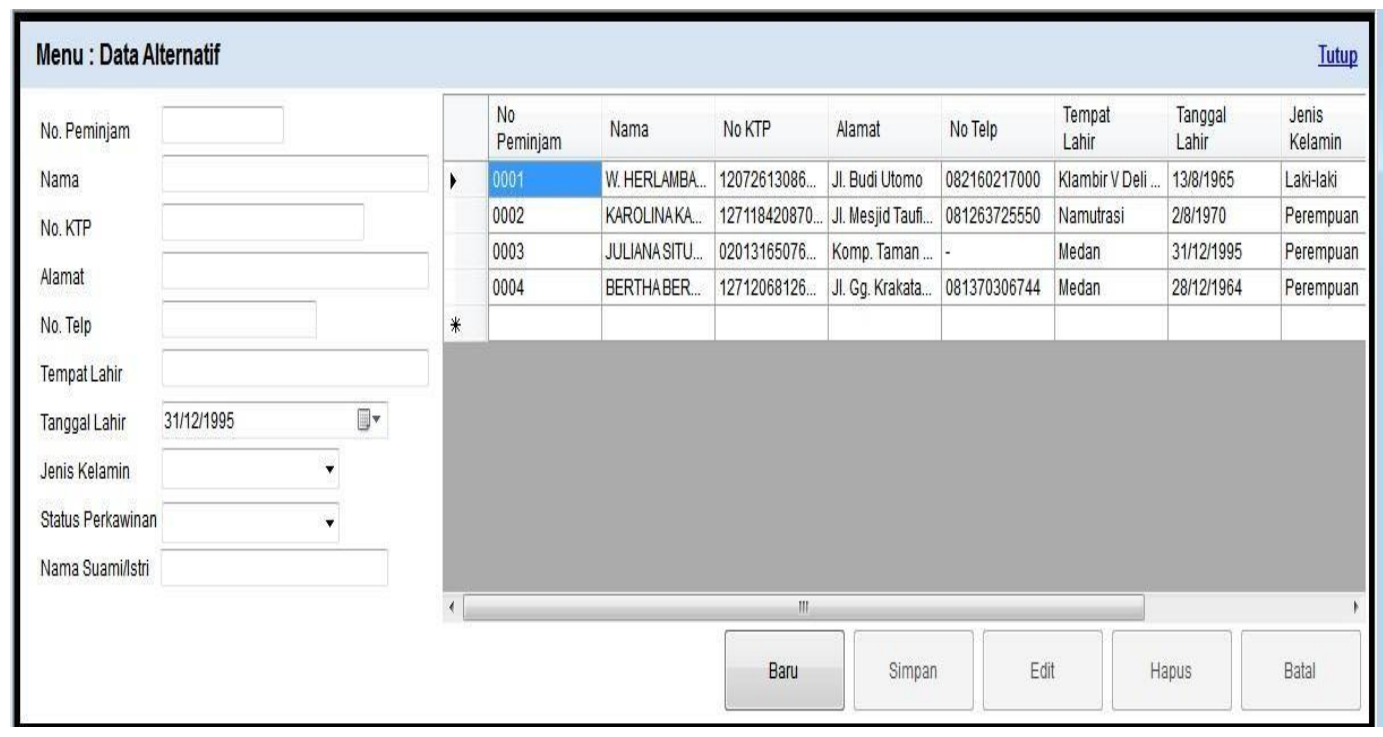

Figure 3 : Alternative Charging Diagram

Before carrying out the AHP process, data is first filled in the pairwise comparison of criteria and sub-criteria. In filling out the pairwise comparison criteria, the comparisons that need to be filled in are income-jobs, income-guarantees, income-credit status, employment-security, employment-credit status, and credit-status guarantees. The rest will be filled in automatically by the system.

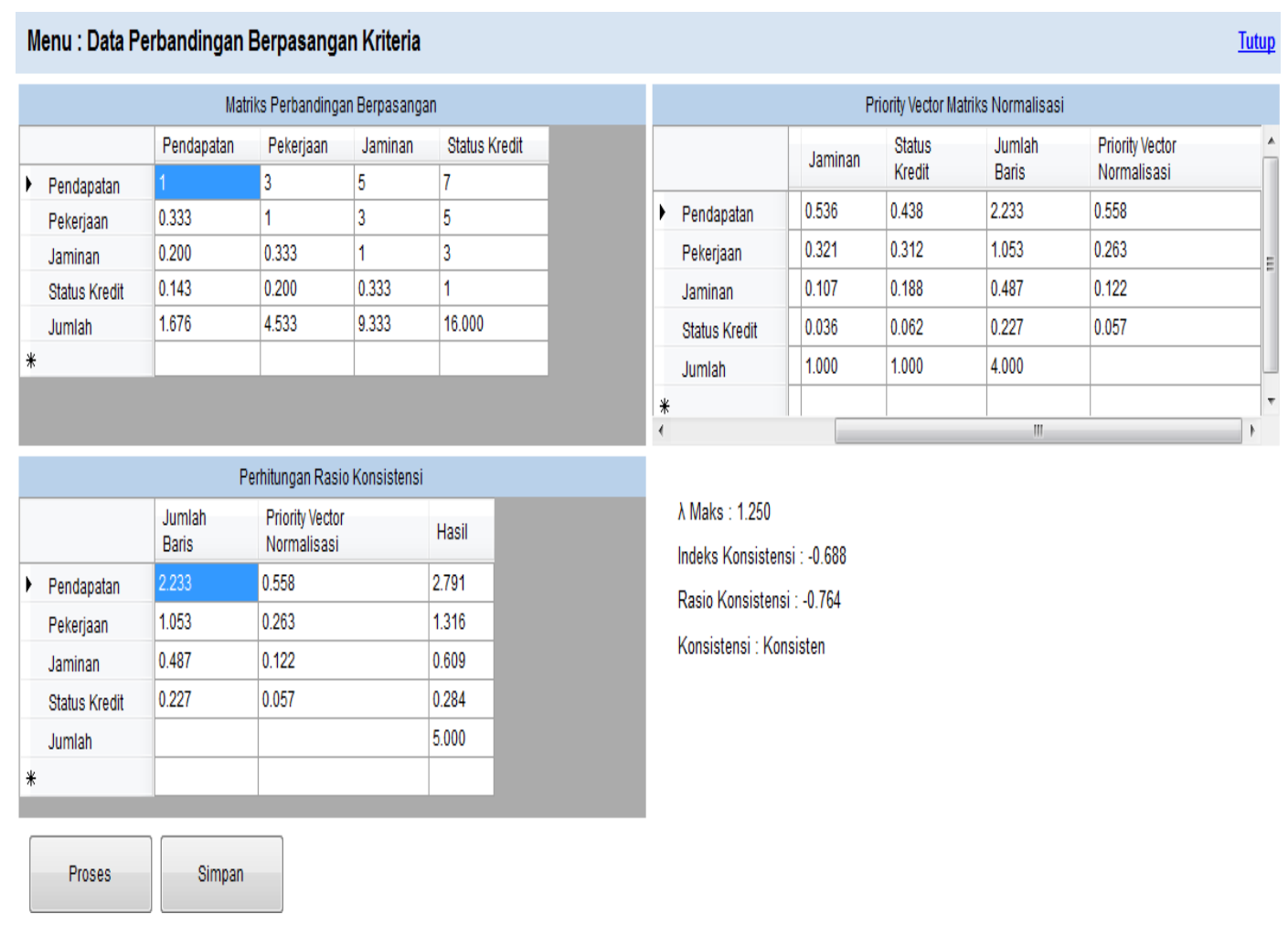

Figure 4 : Comparison Filling in Paired Criteria 
The process of filling in pairs of sub-criteria data is almost the same as filling in paired comparison data for criteria. The process of paired comparison of sub-criteria must be carried out after a paired comparison of criteria.

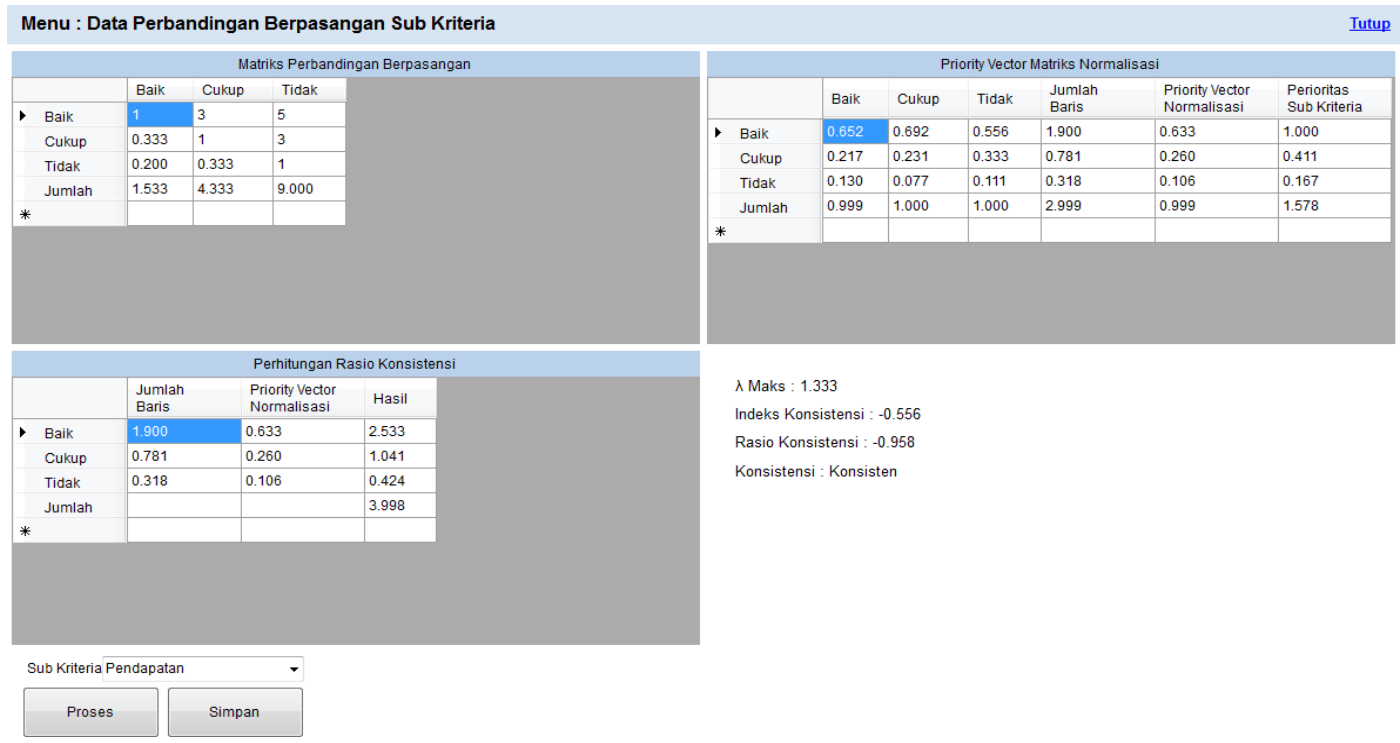

Figure 5 : Comparison of Filling in Paired Sub Criteria

The alternative filling process is to fill in the value of the criteria for each alternative. This filling serves to determine the value of the AHP calculation.

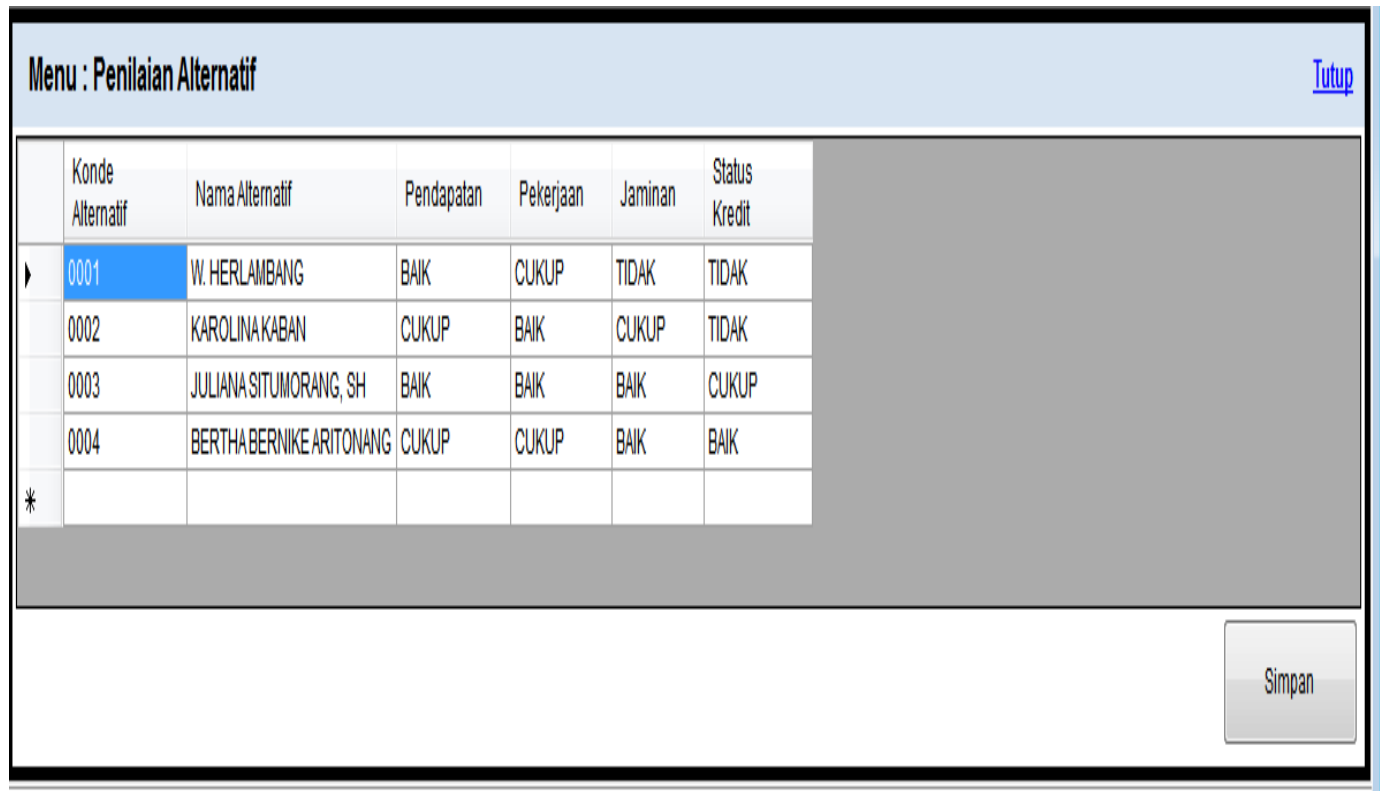

Figure 6 : Filling in the Alternative Assessment

\section{Results from Priority Score Results}

The result of this priority value is to display the table values of the priority results of the criteria with the priority of the sub criteria. 


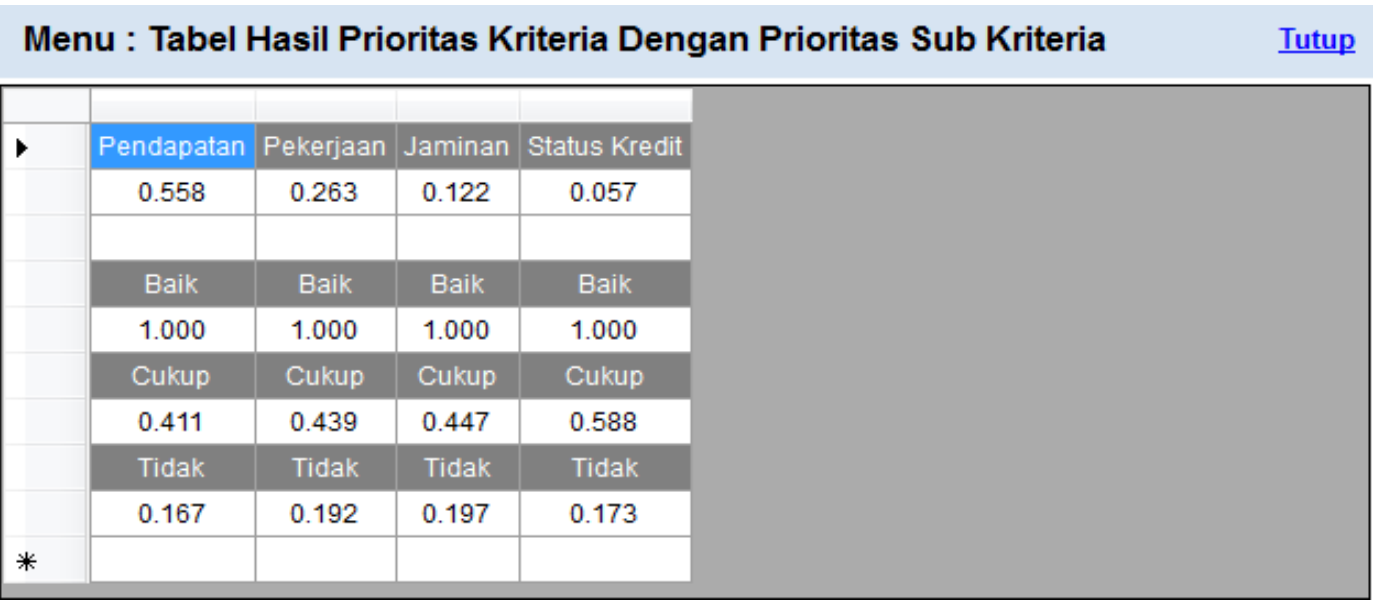

Figure 7 : Priority Value Results

\section{AHP Process}

The AHP process is the last process in a decision support system using the AHP method.

\begin{tabular}{|c|c|c|c|c|c|c|c|c|c|}
\hline \multicolumn{6}{|c|}{ Menu: Proses Analytical Hierarchy Process (AnIP) } & & & & Tutup \\
\hline & Pendapalan & Pekerjaan & Jaminan & Status Kredit & Tolal & \multirow{2}{*}{\multicolumn{2}{|c|}{$\begin{array}{l}\text { No } \\
\text { Peminiam }\end{array}$}} & \multirow{2}{*}{$\begin{array}{l}\text { Nama } \\
\text { Peminjam }\end{array}$} & \multirow{2}{*}{$\begin{array}{l}\text { Rangking } \\
\text { Altemaifi }\end{array}$} \\
\hline I W.HERLAUIBANG & 0.558 & 0.115 & 0.024 & 0.010 & 0.707 & & & & \\
\hline KAROLINAKABAN & 0.229 & 0.263 & 0.055 & 0.010 & 0.557 & 1 & 0003 & 0.977 & JULANASTT \\
\hline JULANASTTUMORANG,SH & 0.558 & 0.263 & 0.122 & 0.034 & 0.977 & & 0001 & 0.707 & W. HERLANIE $=$ \\
\hline BERTHABERNIKEARTTONANG & 0.229 & 0.115 & 0.122 & 0.057 & 0.523 & & 0002 & 0.557 & KAROLINAK \\
\hline \multirow[t]{4}{*}{ * } & & & & & & & 0004 & 0.523 & BERTHABEI \\
\hline & & & & & & * & & & + \\
\hline & & & & & & \multicolumn{3}{|c|}{$1 \longdiv { 1 1 1 }$} & 1 \\
\hline & & & & & & $<$ & > & Hitung & Simpan \\
\hline
\end{tabular}

Figure 8 : Comparison Filling in Paired Sub Criteria

\section{Creating Reports}

Reports in the decision support system aim to store printed files from the decision support system process. There are 3 reports in the decision support system, namely alternative reports, criteria reports and AHP reports, all of which can be processed by clicking on the report menu. Alternative Reports The alternative reports can be seen in the following image: 


\begin{tabular}{|c|c|c|c|c|c|c|c|c|c|c|}
\hline \multicolumn{11}{|c|}{ Menu : Laporan Alternatif } \\
\hline & & $\begin{array}{r}\text { SI } \\
\text { DENGANM }\end{array}$ & $\begin{array}{l}\text { STEMPE } \\
\text { PUSAT } \\
\text { ENGGUN }\end{array}$ & $\begin{array}{l}\text { NDUKUNG } \\
\text { KOPERASIK } \\
\text { AKAN METC }\end{array}$ & $\begin{array}{l}\text { EPUTUS } \\
\text { EPOLISI } \\
\text { OEANAL }\end{array}$ & $\begin{array}{l}\text { AN PEMBER } \\
\text { ANDAERAH } \\
\text { YTICAL HIE }\end{array}$ & $\begin{array}{l}\text { रIAN PINJAM } \\
\text { I SUMATRA L } \\
\text { RARCHY PR }\end{array}$ & $\begin{array}{l}\text { IAN } \\
\text { JTARA } \\
\text { OCESS| }\end{array}$ & (AHP) & \\
\hline \multicolumn{11}{|c|}{ LAPORAN ALTERNATIF } \\
\hline № & No Peminjam & Nama & No KTP & Alamat & No Telp & Tempat Lahir & Tanqqal Lahir & Jenis Kel & Status & Nama Suamil/stri \\
\hline 1 & 0001 & W. HERLAMBANG & $120726130\}$ & Jl. Budi Utomo & 08216021 & Klambir V Deli sı & 08/13/1965 & Laki-laki & Kawin & HARIANI \\
\hline 2 & 0002 & KAROLINA KABAN & $127118420\}$ & $\begin{array}{l}\text { Jl. Mesijd Taufik } \\
\text { No.177 Medan }\end{array}$ & 08126372: & Namutrasi & 08/02/1970 & Perempuä & Kawin & SIMON PASARIBU \\
\hline 3 & 0003 & $\begin{array}{l}\text { JULIANA } \\
\text { SITUMORANG, SH }\end{array}$ & 020131650: & $\begin{array}{l}\text { Komp. Taman } \\
\text { Tenera Indah }\end{array}$ & - & Medan & 12/31/1995 & Perempuc & Kawin & GUNUNG SEMBIRI \\
\hline 4 & 0004 & $\begin{array}{l}\text { BERTHA BERNIIKE } \\
\text { ARITONANG }\end{array}$ & $127120681_{i}^{i}$ & $\begin{array}{l}\text { Jl. Gg. Krakatau } \\
\text { N0.64 Medan }\end{array}$ & 081370301 & Medan & 12/28/1964 & Perempua & Kawin & MARIHOT PASARIE \\
\hline
\end{tabular}

Figure 9 : Alternative Report

\section{The Criteria Report}

The appearance of the criteria report can be seen in the following image:

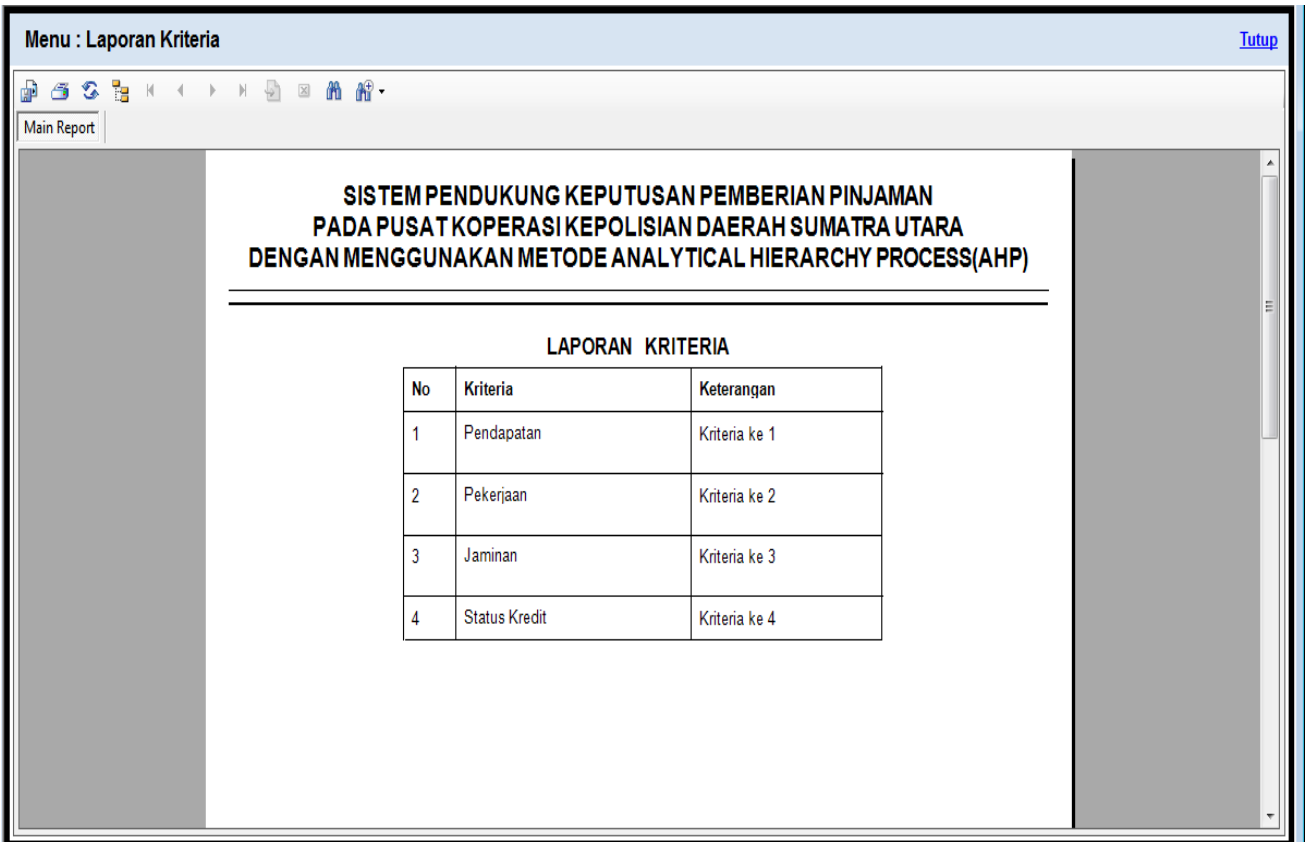

Figure 10 : Criteria Report

The AHP Report The display of the AHP report can be seen in Figure 5.13 below: 


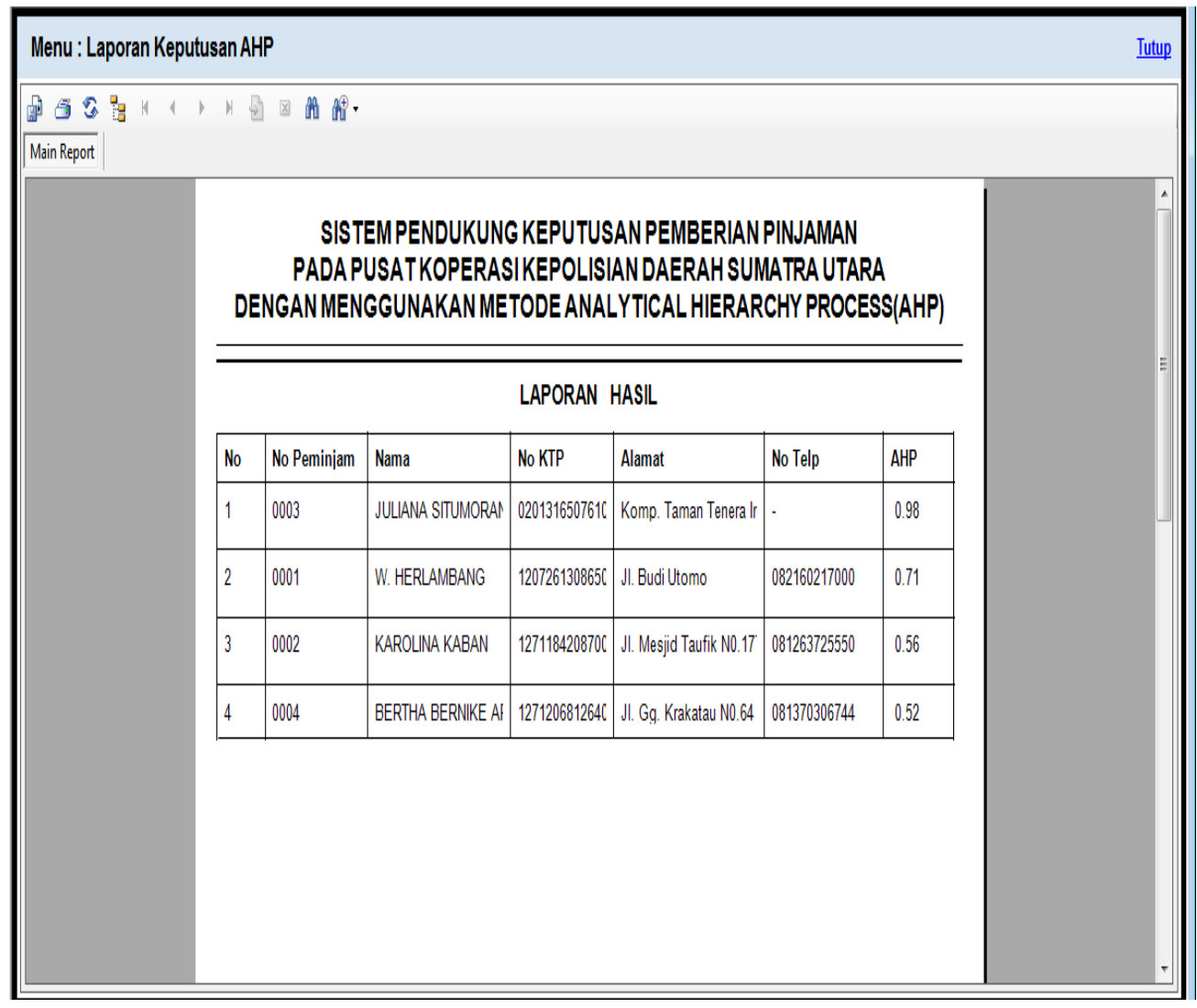

Figure 11 : AHP Report

The following table explains that the criteria or attributes in determining employees who are eligible to receive loans with criteria of income, employment, guarantees and credit status. It is an important point in determining a decent employee.

Table 1: Final Results

\begin{tabular}{ccccc}
\hline Alternative & Income & Work & Guarantee & Credit Status \\
\hline W Herlambang & $0.558 * 1.000$ & $0.263 * 0.439$ & $0.122 * 0.197$ & $0.057 * 0.173$ \\
Karolina Kaban & $0.558 * 0.411$ & $0.263 * 1.000$ & $0.122 * 0.447$ & $0.057 * 0.173$ \\
$\quad \begin{array}{l}\text { Juliana } \\
\text { Situmorang }\end{array}$ & $0.558 * 1.000$ & $0.263 * 1.000$ & $0.122 * 1.000$ & $0.057 * 0.588$ \\
Bertha Bernike & $0.558 * 0.411$ & $0.263 * 0.439$ & $0.122 * 1.000$ & $0.057 * 1.000$ \\
\hline
\end{tabular}

The value $1,000 * 0.558$ in the income column of the row value $\mathrm{w}$ herlambang in the table multiplies each of the priority values of the sub-criteria values of the processing of alternative survey data on the table by the priority values of each criterion on the table, and to look for the values of the other rows, done in the same way. The final step is to calculate the alternate rankings. The results of each criteria column in the table are obtained from the results of multiplication. The results of the calculation can be seen in the table: 
Table 2: Alternatives Ranking

\begin{tabular}{cccccc}
\hline Alternative & \multicolumn{5}{c}{ THE CRITERIA } \\
& income & Work & Certainty & $\begin{array}{c}\text { Credit } \\
\text { Situation }\end{array}$ & Total \\
\hline W Herlambang & 0.558 & 0.115 & 0.024 & 0.010 & 0.707 \\
Karolina Kaban & 0.229 & 0.263 & 0.055 & 0.010 & 0.557 \\
$\quad$ Juliana & 0.558 & 0.263 & 0.122 & 0.034 & 0.977 \\
Situmorang & 0.229 & 0.115 & 0.122 & 0.057 & 0.523 \\
Bertha Bernike & 0.229 & \\
\hline
\end{tabular}

Based on the total column value in the table above, Juliana Situmorang has the highest value, which is 0.977 . Based on the criteria, Juliana Situmorang was selected as a borrower in the regional Kepelosian cooperative.

\section{CONCLUSION}

Based on the results of the discussions that have been carried out previously, it can be concluded that the results of the tests carried out on reference data, the lending process is very dependent on the completeness of the inputted criteria data. Juliana Situmorang has the highest score of 0.977. Based on the criteria, Juliana Situmorang was selected as a borrower in the regional Kepelosian cooperative.

\section{REFERENCES}

[1] C. F. Sitepu and H. Hasyim, "PERKEMBANGAN EKONOMI KOPERASI di INDONESIA," NIAGAWAN, vol. 7, no. 2, 2018, doi: 10.24114/niaga.v7i2.10751.

[2] D. Puspitasari, "RANCANG BANGUN SISTEM INFORMASI KOPERASI SIMPAN PINJAM KARYAWAN BERBASIS WEB,”J. Pilar Nusa Mandiri, vol. XI, no. 2, 2016.

[3] Dani Anggoro, M. D. Umar, E. Vinanty, and D. Dananjaya, "Rancangan Sistem Informasi Koperasi Simpan Pinjam Guru Dan Pegawai Pada Koperasi Smk Manggala Tangerang,” Semin. Nas. Teknol. Inf. dan Komun. 2015 (SENTIKA 2015) Yogyakarta, 28 Maret 2015, vol. 2015, no. Sentika, 2015.

[4] I. G. T. Isa and G. P. Hartawan, "Perancangan Aplikasi Koperasi Simpan Pinjam Berbasis Web (Studi," J. Ilm. Ilmu Ekon., vol. 5, no. 10, 2017.

[5] T. B. Budiyono and C. M. Indah, "TATAKELOLA KOPERASI DI SALATIGA," Masal. Huk., vol. 46, no. 3, 2018, doi: 10.14710/mmh.46.3.2017.257-266.

[6] Y. Eka and E. Arviana, "Sistem Informasi Pendapatan Jasa pada Koperasi PDAM Tirta Patriot Bekasi," J. Tek. Komput. AMIK BSI, vol. 4, no. 1, 2018.

[7] $\quad$ E. P. L. Achmad Solihin, "Sejarah Koperasi," LinkedIn Learn., 2018.

[8] H. and T. W.R.Maya, Implementasi Sistem Pendukung Keputusan Menentukan Tunjangan Kinerja Pegawai Radio Republik Indonesia Menggunakan Metode Analytic Hierarchy Process (AHP), vol. 1, no. 2. 2018.

[9] G. P. Sanyoto, R. I. Handayani, and E. Widanengsih, "Sistem Pendukung Keputusan Pemilihan Laptop Untuk Kebutuhan Operasional Dengan Metode AHP (Studi Kasus: Direktorat Pembinaan Kursus Dan Pelatihan Kemdikbud)," J. Pilar Nusa Mandiri, vol. 13, no. 2, 2017.

[10] R. S. Hutasoit, A. P. Windarto, D. Hartama, and S. Solikhun, "SISTEM PENDUKUNG KEPUTUSAN PEMILIHAN GURU TERBAIK PADA SMK 
MARIA GORETTI PEMATANGSIANTAR MENGGUNAKAN METODE SIMPLE ADDITIVE WEIGHTING (SAW)," Jurasik (Jurnal Ris. Sist. Inf. dan Tek. Inform., vol. 1, no. 1, 2017, doi: 10.30645/jurasik.v1i1.9.

[11] I. chaidir Ishak, A. Sinsuw, and V. Tulenan, "Sistem Pendukung Keputusan Kelayakan Sertifikasi Guru Menggunakan Metode Simple Additive Weighting (SAW)," J. Tek. Inform., vol. 10, no. 1, 2017, doi: 10.35793/jti.10.1.2017.15923.

[12] R. M. Simanjorang, H. D. Hutahaean, and H. T. Sihotang, "Sistem Pendukung Keputusan Penentuan Penerima Bahan Pangan Bersubsidi Untuk Keluarga Miskin Dengan Metode AHP Pada Kantor Kelurahan Mangga," J. Inform. Pelita Nusant., vol. 2, no. 1, 2017.

[13] A. Supriadi, Analytical Hierarchy Process (AHP) Teknik Penentuan Strategi Daya Saing Kerajinan Bordir. 2018.

[14] A. Munthafa and H. Mubarok, "Penerapan Metode Analytical Hierarchy Process Dalam Sistem Pendukung Keputusan Penentuan Mahasiswa Berprestasi," J. Siliwangi, vol. 3, no. 2, 2017.

[15] F. P. Saputra, N. Hidayat, and M. T. Furqon, "Penerapan Metode Fuzzy Analytical Hierarchy Process ( F-AHP ) Untuk Menentukan Besar Pinjaman Pada Koperasi," J. Pengemb. Teknol. Inf. dan Ilmu Komput., vol. 2, no. 4, 2018.

[16] U. S. Utara, "KAJIAN METODE ANALYTICAL HIERARCHY PROCESS (AHP) UNTUK OPTIMISASI PROSES SELEKSI PINJAMAN MODAL USAHA BAGI NASABAH," RISKA DWI FEBRIANI Fak. Mat. DAN ILMU Pengetah. ALAM Univ. SUMATERA UTARA MEDAN, 2018.

[17] B. M. I. Pangestu and S. Anwar, "Pemodelan sistem pendukung keputusan pemberian kredit dengan metode ahp berbasis web mobile 1,2," Pemodelan Sist. Pendukung Keputusan Pemberian Kredit Dengan Metod. Ahp Berbas. Web Mob., 2018. 